Chirurgia (2017) 112: 714-725

No. 6, November - December

Copyright $\odot$ Celsius

http://dx.doi.org/10.21614/chirurgia.112.6.714

\title{
Laparoscopic HIPEC for Peritoneal Carcinomatosis from Gastric Cancer - Technique and Early Outcomes of Our First Cases
}

\author{
Irina Bălescu, Daniela Godoroja, Mircea Gongu, Victor Tomulescu, Cătălin Copăescu \\ Ponderas Academic Hospital, Bucharest, Romania
}

Corresponding author:

Catalin Copaescu, MD PhD

Associated Professor of Surgery

Head of Minimal Invasive and

Metabolic Surgery Department

Director of the Bariatric \& Metabolic

Surgery Program

Bariatric Center of Excellence IFSO

EAC-EC and SRC International Center

of Excellence

PONDERAS Hospital, Bucharest,

Romania

E-mail: catalincopaescu@gmail.com catalin.copaescu@ponderas-ah.ro

\section{Rezumat \\ HIPEC laparoscopic în carcinomatozele de origine gastrică - detalii de tehnică și rezultate precoce ale cazurilor noastre inițiale}

Cancerul gastric rămâne una din cele mai agresive malignități, fiind asociat cu rezultate terapeutice nesatisfăcătoare, în special la pacienții cu boală avansată. Din cauza acestui aspect atenția comunității medicale actuale este concentrată în a identifica un tratament mai bun, un control mai eficient al bolii şi în a îmbunătăti ratele de supraviețuire. Odată ce beneficiile chirurgiei citoreductive în asociere cu hipertermia intraperitoneală (HIPEC) au fost demonstrate pe scală largă la pacienții diagnosticați cu carcinomatoză peritoneală din origine colorectală sau ovariană, atenția a fost axată pe posibila utilizare a acestei metode la pacienții diagnosticați cu carcinomatoză peritoneală de origine gastrică. Mai mult decât atât, prin utilizarea laparoscopiei pentru efectuarea chirurgiei citoreductive (L-CRS) în asociere cu chimioterapia hipertermică intraperitoneală (L-HIPEC), se aşteaptă ca beneficiile intervenției chirurgicale minimal invazive (MIS) să contribuie la îmbunătățirea rezultatelor postoperatorii. În acest mod, pacienții beneficiază de o administrare mai rapidă a tratamentului chimioterapeutic adjuvant ori de câte ori este necesar.

Scop: de a prezenta tehnica L-CRS + L-HIPEC şi rezultatele obținute într-o serie de cazuri de doi pacienți diagnosticați cu carcinomatoză peritoneală din cancerul gastric.

Metodă: În toate cazurile, a fost efectuată o procedură completă de investigare, incluzând laparoscopia exploratorie pentru evaluarea Indexului de Carcinomatoză Peritoneală (PCI). Consiliul 
Instituțional de dezbatere a patologiei tumorale (Tumor Board) a decis strategia terapeutică: rezecția radicală laparoscopică şi HIPEC (L-CRS + L-HIPEC). Procedurile au fost efectuate într-un cadru privat (Ponderas Academic Hospital).

Rezultate: În studiu au fost incluşi doi pacienți de sex masculin în vârstă de 46 şi 69 de ani diagnosticați cu carcinomatoză peritoneală cu origine gastrică. PCI inițial a fost evaluat prin laparoscopie şi a fost de 18 şi respectiv 7 . Ambele cazuri au fost supuse chimioterapiei neoadjuvante. Ulterior a fost efectuată gastrectomia radicală laparoscopică D2 şi L-HIPEC. Timpul de procedură a fost de 360 şi respectiv 320 de minute. Temperatura intraperitoneală a variat între 41 şi $42^{\circ} \mathrm{C}$, în timp ce temperatura intra-esofagiană a atins o valoare maximă de $37,7^{\circ} \mathrm{C}$. Nu a existat nici o complicație perioperatorie sau postoperatorie. Durata despitalizare a fost de 8 zile.

Concluzii: Laparoscopia exploratorie poate ajuta la selectarea pacienților pentru chimioterapia de conversie în cazurile cu indice crescut de carcinomatoză peritoneală (PCI). Rezecția radicală laparoscopică + L-HIPEC au fost efectuate cu succes cu rezultate ulterioare favorabile.

Cuvinte cheie: HIPEC, carcinomatoză peritoneală, neoplasm gastric, chirurgie de debulking, laparoscopie

\begin{abstract}
Gastric cancer remains one of the most aggressive malignancies, being associated with very poor therapeutic outcomes, especially in the advanced disease patients. Due to this evidence, finding a better treatment, a better control and higher survival rates is the current scientific focus of the medical community. Once the benefits of cytoreductive surgery in association with intraperitoneal hyperthermy (HIPEC) have been widely demonstrated in patients presenting peritoneal carcinomatosis from colorectal or ovarian origin,attention was focused on the possible benefit of this method in patients diagnosed with peritoneal carcinomatosis with gastric origin. Moreover, using laparoscopy for the cytoreductive surgery (L-CRS) and hyperthermic intraperitoneal chemotherapy (L-HIPEC), the advantages of minimal invasive surgery (MIS) are expected to contribute to improved postoperative outcomes. In this way, the patients benefit from a faster administration of the adjuvant chemotherapeutic treatment, whenever is necessary.

Aim: to present the technique of L-CRS + L-HIPEC and the early therapeutic outcomes in a case series of two patients diagnosed with peritoneal carcinomatosis from gastric cancer.

Method: A complete investigational work-up including diagnostic laparoscopy to evaluate the Peritoneal Carcinomatosis Index (PCI) was fulfilled in all the cases. The institutional Tumor Board decided the therapeutic strategy: laparoscopic radical resection and HIPEC (L-CRS +L-HIPEC). The procedures were performed into a private setting (Ponderas Academic Hospital).

Results: Two male patients, 46 and 69years old, presenting carcinomatosis from gastric cancer were included into the study. Initial PCI was assessed by laparoscopy and it was 18 and 7, respectively. Both cases underwent neoadjuvant chemotherapy. D2 laparoscopic radical gastrectomy and L-HIPEC was then performed. Time of procedure was360 and 320 minutes, respectively. The intraperitoneal temperature varied between 41 and $42^{\circ} \mathrm{C}$, while the intra-esophageal temperature reached a maximum value of $37,7^{\circ} \mathrm{C}$. There was no perioperative or postoperative complication, nor mortality. The hospital stay was 8 days.

Conclusions: Explorative laparoscopy can help select patients for conversion chemotherapy in the setting of high peritoneal carcinomatosis index (PCI) score. Laparoscopy radical excision + L-HIPEC were successfully performed with very good therapeutic outcomes.
\end{abstract}

Key words: HIPEC, peritoneal carcinomatosis, gastric cancer, debulking surgery, laparoscopy 


\section{Introduction}

Gastric cancer remains one of the most aggressive malignancies especially due to the fact that most cases are diagnosed in advanced stages of the disease, when the risk of developing peritoneal carcinomatosis is significantly higher. Moreover, in up to $25 \%$ of cases presenting recurrent tumors, the disease will be confined to the peritoneum (1-3); due to this reason, attention was focused on finding a therapeutic option which could stop the intraabdominal evolution of the metastatic process. The efficacy of cytoreductive surgery which was widely demonstrated in cases diagnosed with peritoneal carcinomatosis from colorectal, appendicular or ovarian origin, and the common pattern of intraperitoneal spread reported in advanced stage gastric cancer encouraged surgeons worldwide to apply this therapeutic protocol in patients with peritoneal carcinomatosis originating from gastric cancer (3-5). However, it should not be omitted that the association of cytoreductive surgery and HIPEC in patients with peritoneal carcinomatosis from gastric cancer can significantly increase the postoperative morbidity, a careful selection of the patients being mandatory (6).

The peritoneal carcinomatosis index (PCI) is a carcinomatosis assessment being determined at the time of surgical exploration of the abdomen and pelvis and it was firstly introduced by Paul Sugarbaker (7). He proposed the division of the abdominal cavity in 13 areas; in the mean-time the tumor burden in each abdominal area is quantified between 0 and 3 , depending on the tumoral volume ( 0 for areas with no visible tumors, 1 for the areas in which the largest tumoral volume is $<0,5 \mathrm{~cm}, 2$ for the areas with the largest tumoral volume $<5 \mathrm{~cm}$ and 3 for the areas with tumors larger than 5 $\mathrm{cm}$ or with confluent lesions). According to Jacquet and Sugarbaker, the value of PCI is calculated by summing the score of the lesion for each area; the PCI values range between 0 (for patients with no peritoneal lesions) and 39 (for patients with tumors larger than $5 \mathrm{~cm}$ or confluent lesions in all areas). PCI was later validated and widely accepted to evaluate peritoneal carcinomatosis (8).

The encouraging results presented by the studies analyzing the effect of HIPEC on carcinomatosis after gastric cancer $(9,10)$, the support, training and mentorship offered to our team by the team of Professor Marc Pocard, Lariboisière Hospital, France, as well our extensive experience in minimal invasive surgical oncology were determinant factors to introduce the L-HIPEC in our institution. The Ethical Committee Approval was obtained.

Our study's aim was to evaluate the laparoscopic technique and the early therapeutic outcomes in a case series of two patients diagnosed with peritoneal carcinomatosis from gastric cancer that underwent laparoscopic radical excision and L-HIPEC.

\section{Methods}

Our first case series of two patients submitted to laparoscopic cytoreductive surgery and L-HIPEC was analyzed. A complete investigational work-up including diagnostic laparoscopy to evaluate the Peritoneal Carcinomatosis Index (PCI) was fulfilled in all the cases. The Institutional Tumor Board decided the therapeutic strategy: laparoscopic radical resection and HIPEC (L-CRS +L- HIPEC). The Institutional Ethical Board approved the introduction of the L-HIPEC procedure in these cases and all the patients signed the informed consent. The procedures were performed in August and September, 2017, into a private setting, (Ponderas Academic Hospital).

The main criteria of inclusion for HIPEC in peritoneal carcinomatosis with gastric origin were respected: age of the patient (under 70 years), a good biological and nutritional status, the possibility of obtaining a complete cytoreduction (to "no visible" residual disease, an $\mathrm{R} 0$ resection) and the peritoneal carcinomatosis index (under 20) (8).

Preoperative mechanical bowel preparation and perioperative DVT prophylaxis with LMWH extended for 3 postoperative weeks were routinely performed. 


\section{Surgical Technique}

The patient is carefully placed on the operative table in Lloyd Davies position, preventing any postural complication associated with a longlasting procedure. We recommend the use of gel pads, dedicated surgical table supports and belts. In this position the surgeon stands in between the legs of the patient, camera man on the right side, and the assistant surgeon on the left side of the patient. The procedure requires general anesthesia and its technical details are going to be described below. Karl Storz (Tuttlingen, Germany) HD laparoscopic equipment was used in all the cases. After creating the pneumoperitoneum, and the trocar placement, an explorative laparoscopy was performed. The PCI was carefully evaluated as described (11) to assess the condition for radical excision and HIPEC.

Laparoscopic D2 radical gastrectomy was performed as described (12).Omentectomy was performed from the very beginning and it was continued by an en bloc removal of the anterior sheath of the transverse mesocolon using both bipolar and monopolar energy devices. The dissection went further by identifying the main gastro-epiploic pedicles which were clipped and divided at their origin in order to provide an adequate resection of the adjacent lymph node stations. After the complete mobilization of the greater curvature to the left crus and sectioning all the adjacent vascular branches, the duodenum was transected using a $60 \mathrm{~mm}$ Tan linear stapler (Tri-Staple $^{\mathrm{TM}}$ Technology, Medtronic,US) Then the gastric corpus was reclined to the upper pole in order to continue the vascular dissection on the lesser curvature. The right gastric vessels were also clipped and sectioned at the origin while the left gastric vessels were dissected and divided using a $30-\mathrm{mm}$ vascular linear stapling device. Next, the lymph node dissection was performed at the level of the hepatic pedicle and along the splenic vessels (station no 7,8,9,10,11 p, d). The dissection continues $6-8 \mathrm{~cm}$ cranial to the cardia. The esophagus or the proximal stomach is transected using a 60 Purple linear stapler
(Tri-Staple ${ }^{\mathrm{TM}}$ Technology, Medtronic,US) and the specimen is introduced in a $1200 \mathrm{ml}$ Endobag device in order to minimize the risk of intraperitoneal contamination. The next surgical step consists of the specimen extraction via an 8-10 cm Phannenstiel incision, using a wound protector. Monofilament running stitch is used to close the suprapubic laparotomy. The specimen is sent for frozen section in order to confirm the negativity of the surgical margins. (Fig. 1)

Before performing the anastomoses, the vascularization of the anastomotic partners was controlled by indocyanine green (ICG) injection (5 ml,i.v.), in near to red light, using PIN POINT Technology (NOVADAQ, US).

Once the vascular integrity of the anastomotic partners is demonstrated after ICG test, a Roux en $\mathrm{Y}$ anastomosis is performed. The jejuno-jejunal anastomosis is performed by double stapling technique, at $50 \mathrm{~cm}$ from the angle of Treitz, using two $60 \mathrm{~mm}$ linear staplers. Therefore, the esojejunal/gastrojejunal anastomosis is performed using a 25-circular stapler with Orvill technology (Medtronic, US). The Petersen and mesenteric spaces are closed using non-absorbable stitch in order to prevent the development of internal hernias. A feeding nasojejunal tube is also placed under direct visual

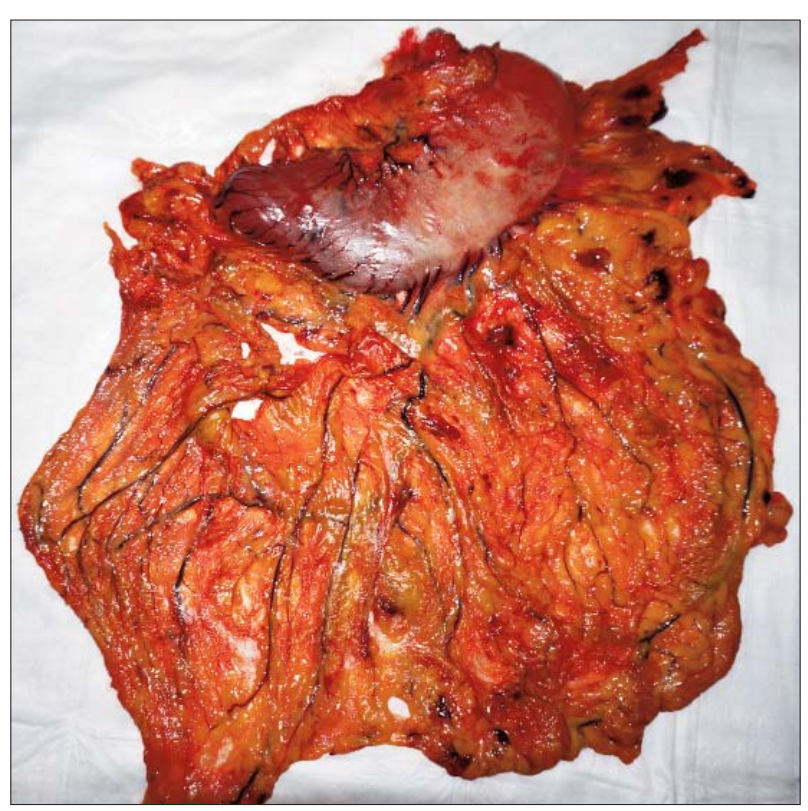

Figure 1. The specimen after laparoscopic radical gastrectomy 

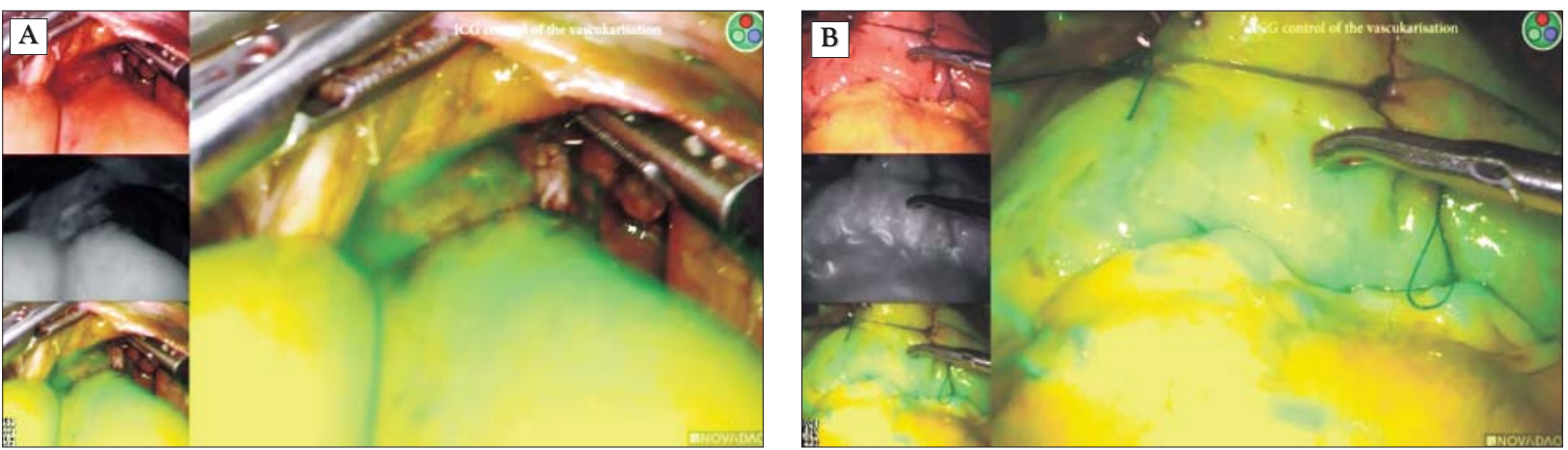

Figure 2. ICG test in infrared revealed a proper vascularization of the eso-jejunal anastomosis (A) and intestinal side-to-side anastomosis (B)

control and the anastomoses are tested by methylene blue injection. ICG test is also performed for both anastomosis (Fig. 2A, 2B).

Once the mechanical/vascular integrity of the anastomoses is demonstrated, two $18 \mathrm{Fr}$ spiral drains are placed in the close proximity of the sutures.

\section{The Laparoscopic HIPEC Technique}

The equipment used for the procedure was consisting of ThermoChem HT-2000 machine and Therma Solutions Procedure Kit (1112000), and it was used for laparoscopic HIPEC in all the cases.

The laparoscopic HIPEC technique consisted in through $15 \mathrm{~mm}$ trocars placing two inflow catheters in the upper abdominal region and two outflow catheters in the Douglas pouch, each catheter being connected to the corresponding thermo-probe (Fig 3). In the meantime each couple of catheter-thermoprobe is introduced in a special protection device in order to minimize the risk of contamination of the surrounding tissues with the chemotherapeutic agent (Figs. 4, 5).

In order to avoid the temperature fluctuation, the air conditioning device in the operating room will be turned off while the ventilation system will be turned to diminish the risk of accumulation of the toxic steam. Moreover, all the liquids which are recycled are kept in special devices which will limit the risk of contamination. Once the procedure is started, maximum three persons from the anesthesiology and surgical team will stay in the operating room while the access for any other person will be denied until the end of the procedure.

Once the anastomoses were performed and verified, the L-HIPEC procedure was started, a $43^{\circ} \mathrm{C}$ solution of Oxaliplatin $300 \mathrm{mg} / \mathrm{m}^{2}$ being introduced into the peritoneal cavity and recirculated for 30 minutes. The chemotherapic agent was introduced on the two inflow catheters which were placed in the upper abdominal quadrant, in the proximity of the tumor bed and was aspirated on the two outflow catheters which were placed in the Douglas pouch. The intraabdominal temperature was monitored during the procedure by the four thermocouples which were placed at the level of the inflow and respectively of the outflow

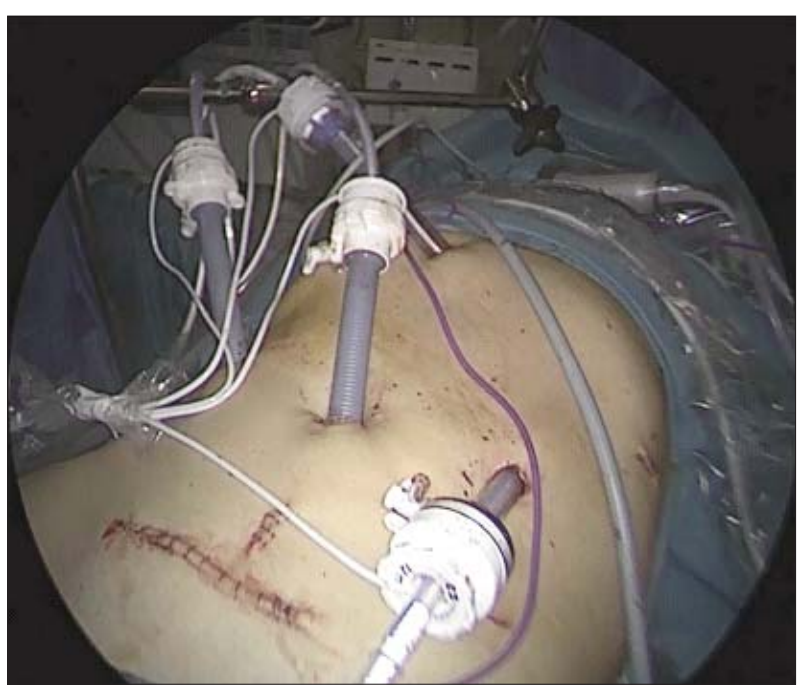

Figure 3. The external aspect: the four catheters have been placed through $15 \mathrm{~mm}$ laparoscopic cannulas 


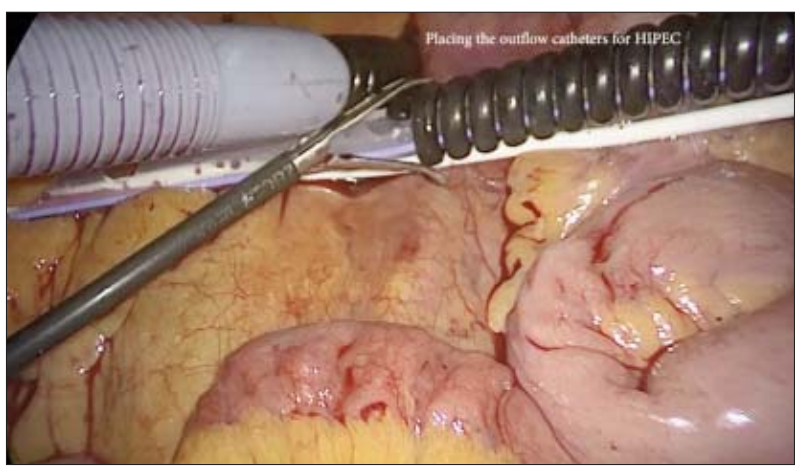

Figure 4. Placing the outflow catheters and the corresponding thermocouples in the pelvic areas. The two black spirals will prevent the ventousage effect when suctioning the chemotherapeutic agent

catheters and was maintained between 41 and $43^{\circ} \mathrm{C}$. In the meantime, the endo-esophageal temperature level was closely monitored (a value higher than $38^{\circ} \mathrm{C}$ enforcing ending the procedure). In the meantime, one hour before introducing the intraperitoneal agents an intravenous perfusion with 5 fluorouracil $\left(400 \mathrm{mg} / \mathrm{m}^{2}\right)$ and calcium folinate $\left(20 \mathrm{mg} / \mathrm{m}^{2}\right)$ were administrated. Intraoperative parameters of the L-HIPEC procedures are shown in Figs. 6-8.

\section{Anesthetic Management}

The anesthetic preparation included insertion of a peripheral line $14 \mathrm{G}$ for rapid volemic repletion, a T7-T10 thoracic epidural catheter for pain relief, an arterial line and four lumen

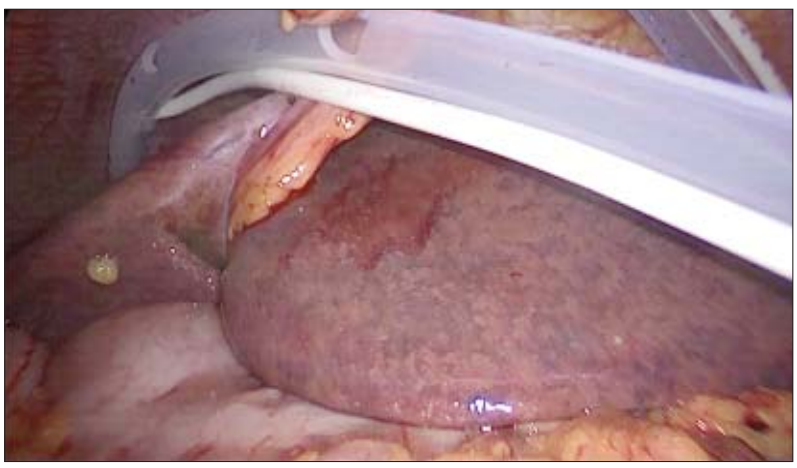

Figure 5. Placing the inflow catheters with the corresponding thermocouples in the upper abdomen, in close proximity with the tumoral bed

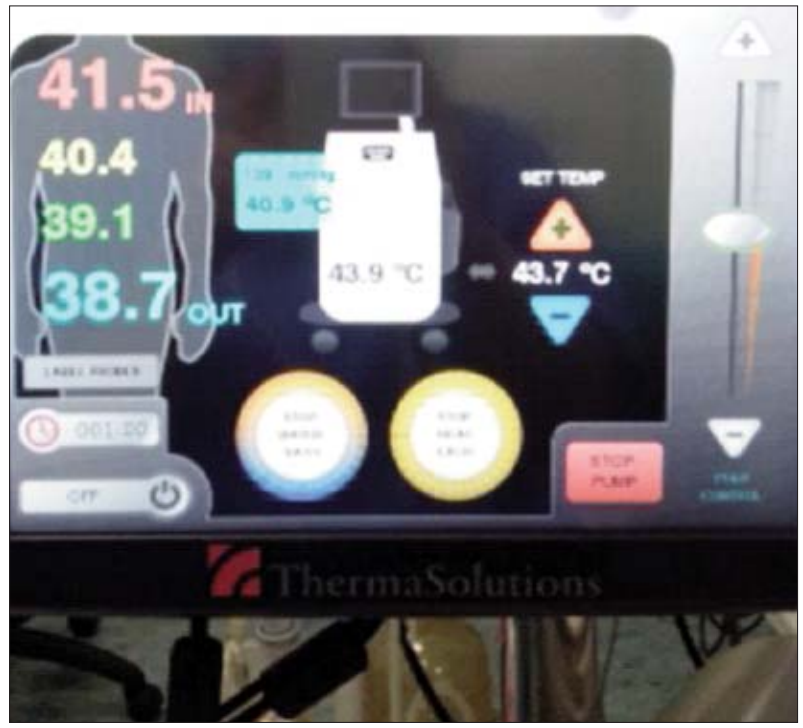

Figure 6. Monitoring the intraperitoneal temperature during the L-HIPEC procedure
Figure 7. Registration of intraperitoneal temperature at the level of the four intraperitoneal thermocouples demonstrating that the temperature was maintained at a constant level during the whole length of the procedure (for 30 minutes - between the initial moment - at 7 hours: 04 minutes: 23seconds and the final moment - at 7 hours:44 minutes :38 seconds)

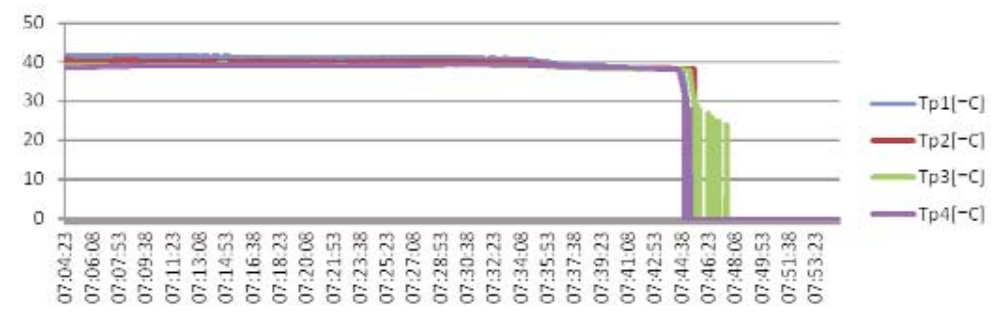

$\operatorname{Twb}[-\mathrm{C}]$

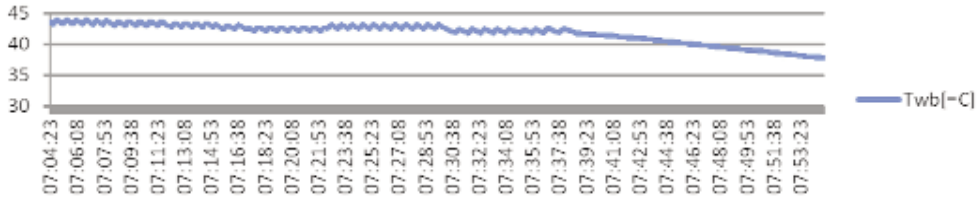

Figure 8. The water bath temperature - generated by the HIPEC machine was maintained at $43-44^{\circ} \mathrm{C}$ during the whole procedure 
Central Venous Catheter with one lumen serving for IV chemo delivery. Bair- Hugger warming and warming infusion devices were used. Three units of cross-matched blood and fresh frozen plasma were available for use $(13,14)$.

Peritonectomy with HIPEC can be divided into two phases, the cyto-reduction phase and the HIPEC phase(15). Each phase has specific pathophysiological changes and intraoperative particularities for anaesthetic management. The cytoreduction phase, is presenting, as expected to, large blood and fluid losses from exposure in the surgical field and diuresis. Those losses were replaced with infusion of crystalloids and colloids. It was also necessary to replace blood components as a consequence of changes in levels of coagulation, platelet count, and haematocrit.Intraoperative fluid management is crucial for the outcome and success of surgery, especially in high-risk procedures. Maintenance of intravascular fluid balance was acquired by goal-directed therapies (16) and minimally invasive hemodynamic monitoring. The preload (Stroke Volume Variation -SVV), contractility (Cardiac Output CO) and afterload (Systolic Blood Pressure) are the main parameters used to guide fluid administration and hemodynamic management. The arterial pressure based cardiac output (APCO) is a CO monitoring system based on the analysis of the systemic arterial pressure wave form and back calculate the stroke volume (SV) (17). Adequate volume replacement to achieve optimal cardiac performance is critical in hemodynamic management in order to prevent any deleterious consequence of under-resuscitation or fluid overload. However, in only half of these patients, the CO increases after the fluid administration and thus only these can be considered as responders to fluid therapy,so that the vasopressors are frequently administered. We used Pulse Contour Cardiac Output (PiCCO Pulsion Medical SystemsMaquet Getinge Group) and EV 1000 (Edwards Lifescience) platforms for goal directed therapy for fluid management in the two patients and both received vasopressors during and in the first hours post intervention.
During the HIPEC phase an increase in heart rate is expected, due to the elevation in body temperature and airways pressure. The patient MUST be paralyzed for the duration of the intraperitoneal chemotherapy treatment. Coughing or movement during chemotherapy can lead to a major chemotherapy spill. As, Oxaliplatin is renally excreted and the systemic absorption is minimal, we recommend maintaining good urine output during the chemo instillation. The chemo is delivered in 3 liters of D5W. Transient hyperglycemia may result. Blood glucose should be monitored at the completion of chemo delivery, and occasionally a single dose of insulin may be required. Similar to other reports (14) the patients were transferred to the ICU intubated, being extubated in the first 12 hours postoperative period. Postoperative analgesia was achieved with a combination of boluses of opioids and local anaesthetics through the epidural catheter, and multimodal analgesia.

All anaesthetic issues are shown in Table 1.

Due to theaggressivity and particularities of the surgery, the anaesthesiologists have a decisive role in the immediate control of any clinical change of the patients.

\section{Case 1}

Our first case was a69-year-old male patient, presenting evidence of moderately differentiated antral, partially obstructive, gastric adenocarcinoma - revealed by upper endoscopy and biopsy - with peritoneal disseminations - demonstrated by computer tomography, in June 2017. The Institutional Tumor Board has decided to complete the diagnostic work-up with explorative laparoscopy in order to assess the initial PCI and to establish a valid route for enteral nutrition before the initiation of the neoadjuvant therapy.

During the explorative laparoscopy the extension of peritoneal carcinomatosis was evaluated and the initial PCI was 18. A laparoscopic Roux-e-Y Gastroenterostomy at $50 \mathrm{~cm}$ from Treitz angle was also performed (in order improve the nutritional status) followed by seven cycles of neoadjuvant 
Table 1.

\begin{tabular}{|c|c|}
\hline Issue & Procedure \\
\hline Fluid repletion & $\begin{array}{l}\text { - Goal directed therapy-10-18 ml/kg/h } \\
\text { - Crystalloids(Saline plus Ringer Lactate or Prismasol) }\end{array}$ \\
\hline Temperature & $\begin{array}{l}\text { Before HIPEC }-36-36,5 \text { IC to prevent the thermal shock } \\
\text { - Stop the warming } 30 \text { min before HIPEC } \\
\text { - First alert at } 38^{\prime} \mathrm{IC} \text { during HIPEC } \\
\text { - Stop HIPEC at } 39^{\prime} \mathrm{IC} \text { and start the patient cooling }\end{array}$ \\
\hline Parlyse the patient & $\begin{array}{l}\text { - The patient MUST be paralyzed for the duration of the } \\
\text { intraperitoneal chemotherapy treatment and give Morphine. } \\
\text { - Continuous infusion of the neuromuscular blocking agents } \\
\text { is recommended }\end{array}$ \\
\hline Urine output & $\begin{array}{l}\text { Oxaliplatin is renally excreted-maintaining good urine } \\
\text { output during the chemo instillation }(0.5-1 \mathrm{~mL} / \mathrm{kg} / \mathrm{hr}) \text {. }\end{array}$ \\
\hline Monitor blood glucose & $\begin{array}{l}\text { - The chemo is delivered in } 3 \text { litres of D5W. } \\
\text { - Transient hyperglycaemia may result. }\end{array}$ \\
\hline
\end{tabular}

chemotherapy (Oxaliplatin - $85 \mathrm{mg} / \mathrm{m}^{2}$, 5 fluorouracil $-2400 \mathrm{mg} / \mathrm{m}^{2} / 46$ hours, calcium folinate $400 \mathrm{mg} / \mathrm{m}^{2}$ ) After ending the neoadjuvant chemotherapy a computed tomography scan was performed and it revealed a moderate regression of the gastric tumor as well as the regression of the peritoneal carcinomatosis nodules. The patient was resubmitted to surgery, this time with curative intent; during the explorative laparoscopy the PCI was recalculated, a value of 7 being revealed. A laparoscopic subtotal gastrectomy with Roux en Y gastrojejunal anastomosis, D2 lymph node dissection and total omentectomy was performed; an $\mathrm{R} 0$ resection proved by the intraoperative histology has being achieved. Once the cytoreductive phase was ended, the vascularization of the anastomotic partners was checked by the ICG test, than the HIPEC procedure was initiated as described. The intraperitoneal temperature varied between 41 and $42^{\circ} \mathrm{C}$ while the intra-esophageal temperature reached a maximum value of $37,7^{\circ} \mathrm{C}$. There was no perioperative or postoperative complication. The patient remained in the intensive care unit for the next six days and was submitted to a Gastrographyn enema in the fifth postoperative day. The enteral nutrition was reintroduced form the seventh postoperative day. The postoperative course was uneventful, the patient being discharged in the eighth postoperative day. The postoperative evolution was uneventful. The histopathological studies revealed the presence of a moderately differentiated gastric adenocarcinoma, with four positive lymph nodes out of the 22 resected lymph nodes.

\section{Case 2}

A 46-year-old patient was diagnosed with a well differentiated gastric adenocarcinoma of the lesser curvature, with cardial involvement. The patient was submitted to six cycles of neoadjuvant chemotherapy (Docetaxel 50 $\mathrm{mg} / \mathrm{m}^{2}$, calcium folinate $400 \mathrm{mg} / \mathrm{m}^{2}$ - bolus, 5 fluorouracil - $400 \mathrm{mg} / \mathrm{m}^{2}$ - bolus followed by $2600 \mathrm{mg} / \mathrm{m}^{2} / 24$ hours and Oxaliplatin $85 \mathrm{mg} / \mathrm{m}^{2}$ ) with a good clinical response (he gained seven kilograms under chemotherapy). One month after ending the neoadjuvant treatment the patient was submitted to surgery, a total esogastrectomy with Roux en Y eso-jejunostomy, D2 lymph node dissection and omentectomy being performed. At the beginning of the surgical procedure the PCI was 2 while at the end of the procedure there was no visible intraabdominal tumoral lesion, a complete cytoreduction being achieved. At the end of the debulking phase an ICG test of the vascularization was performed followed by the HIPEC procedure (as described). The intraperitoneal temperature varied between 41 and $43^{\circ} \mathrm{C}$, while 
the intra-esophageal temperature reached a maximum value of $37,9^{\circ} \mathrm{C}$. There was no perioperative or postoperative complication. The patient remained in the intensive care unit for the next five days and was submitted to a barium enema in the sixth postoperative day. The enteral nutrition was reintroduced form the seventh postoperative day. The histopathological studies revealed the presence of a well differentiated gastric adenocarcinoma, with no positive lymph nodes out of the 22 resected lymph nodes.

\section{Discussions}

The poor prognosis of advanced stage gastric cancer patients is most often related to the presence of nodal involvement and/or to the presence of peritoneal dissemination. While the tumor stage at diagnostic is most often responsible for the apparition of the local recurrences, the nodal involvement is usually associated with the apparition of distant metastases. Moreover, the presence of tumoral peritoneal seeding in the close proximity of the tumor will lead to the development of peritoneal carcinomatosis at a certain point of the evolution of such patients $(18,19)$. Peritoneal carcinomatosis with gastric cancer origin has been commonly seen as a terminal event, with high mortality rates within the next six months irrespectively of the performed therapeutic strategy $(2,20)$. The largest studies regarding the benefits of systemic chemotherapy in such cases failed to demonstrate a benefit in terms of survival; the best outcomes have been reported in cohorts which includedboth advanced stage gastric cancer in the absence of peritoneal lesions as well as the patients with peritoneal carcinomatosis with gastric origin, in these cases the cumulative median overall survival being of up to 10 months $(21,22)$.

The reported benefits in terms of survival in patients diagnosed with peritoneal carcinomatosis from colorectal or ovarian origin submitted to HIPEC enabled the surgeons worldwide to propose this therapeutic strategy in peritoneal carcinomatosis with gastric cancer origin too $(7,23)$. The main goal of this procedure is to excise all macroscopic potential positive structures and treat the peritoneal cavity with heated chemotherapeutic agents in order to destroy the remnant microscopic disease. It has been demonstrated that intraperitoneal administration of heated chemotherapeutic agent is able to penetrate the tissues up to $3 \mathrm{~mm}$ in depth (24). By direct delivery of the cytotoxic agent in the peritoneal cavity it is estimated that a higher intracellular concentration of the chemotherapeutic substance will be achieved and the tumoral cells will be destroyed; the main incriminated mechanisms at this moment consist of apoptosis induction as well as impairing the DNA repair (9). Other mechanisms of action of HIPEC consist of decreasing the cellular perfusion, increasing the lysosomal activity and induction of acidosis (25-27). Moreover, it has been proven that the combination of hyperthermia and chemotherapy will lead to the apparition of a synergic effect increasing in this way the efficacy of the procedure. Another advantage of the intraperitoneal route of administration of various types of chemotherapeutic agents consists in the limitation of the systemic cytotoxicity. Therefore, HIPEC has been proposed in advanced stage gastric cancer in cases presenting peritoneal lesions (with curative intent) but also in the absence of macroscopic visible peritoneal lesions (with prophylactic intent) $(28,29)$.

However, not all the patients diagnosed with advanced stage gastric cancer in the presence or in the absence of peritoneal carcinomatosis are candidates for HIPEC. It should not be omitted that this procedure might induce serious adverse effects; therefore, it is strongly recommended that the patients who will be submitted to HIPEC to have a good biological and clinical status (ECOG performance status $<2$ ), to have limited intraperitoneal lesions (estimated through a PCI lesser than 20 ) and not to have any sign of extra-abdominal disease (7).

When it comes to the risk of developing postoperative complications, initially it had been considered that association between 
resection and HIPEC in the same surgical procedure might lead to a significant increase of the postoperative complications; therefore, some studies recommended a sequential approach: cytoreductive surgery as the first intent treatment, followed by staged intraperitoneal chemo hyperthermia(5). However, more recent studies demonstrated that the two therapeutic strategies can be safely performed during the same surgery without inducing a significant increase of the perioperative morbidity (9).

One of the first studies demonstrating the effectiveness of HIPEC in advanced stage gastric cancer with or without peritoneal lesions has been published by a French group almost one decade ago. The study conducted by Scaringi et al. included 37 patients diagnosed with advanced stage gastric cancer which had been submitted to HIPEC between 1992 and 2007 in Paris VII University "Denis Diderot" (9). Among these cases there were 11 patients diagnosed with advanced stage gastric cancer and no macroscopic lesions of peritoneal carcinomatosis, eight patients diagnosed with peritoneal carcinomatosis with gastric origin in whom debulking surgery to no residual disease was achieved and 18 patients in whom an incomplete cytoreductive surgery was performed (due to the presence of bulky unresectable lesions). Although at the end of the resectional phase all patients were submitted to HIPEC with Mitomycin and Cisplatin in the same conditions, the long term outcomes demonstrated that a significant benefit in terms of survival was achieved only in patients with advanced stage gastric cancer in whom macroscopic peritoneal lesions were not present as well as in the cases in which a complete cytoreductive surgery was performed. The median survival in the prophylactic group was 23,4 months, significantly higher when compared to the one reported in the curative intent group (in which the median survival was 15 months) or to those submitted to incomplete cytoreductive procedure (in which the median survival rate was of only 3,9 months). The authors also reported that the recurrence rate at a 2 year follow up was $36 \%$ in the prophylactic intent group and $50 \%$ in the curative intent group. According to the same author, the most impressive case was the one of a 53-year-old male who had been initially submitted to surgery for gastric cancer peritoneal carcinomatosis with curative intent in whom although the histopathological studies demonstrated the presence of a signet ring cell antral carcinoma with nodal invasion (N1) a disease-free interval of 8,7 years was reported (at the time of publishing the article the patient did not report any signs of recurrent disease) (9).

The benefits of prophylactic HIPEC in patients at high risk of developing peritoneal carcinomatosis were also investigated in the Japanese studies. One of the first such papers was published in 1999 by Fujimoto et al. and demonstrated that patients presenting high grade tumors, with serosal invasion submitted to HIPEC reported a higher 8year overall survival rate when compared to their counterparts who had been submitted to radical surgery and adjuvant systemic chemotherapy (62\% versus $49 \%)(10)$.

Another important issue which should be taken in consideration in peritoneal carcinomatosis with gastric cancer origin is the timing of the apparition of the peritoneal lesions; it has been stipulated that patients developing peritoneal carcinomatosis at a certain point of their evolution present in fact a more aggressive biology of the tumor which could not be controlled by the previous administrated treatment and might have a poorer response to HIPEC (14). Oppositely, patients presenting peritoneal carcinomatosis at the moment of the initial diagnosis seem to have a better outcome if cytoreductive surgery to no residual disease and HIPEC are associated.

When it comes to the most appropriate way of delivery of HIPEC, the method was initially imagined in the setting of the open surgery. However, in the last years, once the minimally invasive approach has been widely performed in an increasing number of centers, laparoscopic HIPEC gained popularity $(5,20)$. Initially proposed with palliative intent(30), latter for the pre-therapeutic PCI evaluation 
(31) and to date as part of the therapeutic protocol in unresectable lesions and refractory ascites, later on the method has been also proposed in association with laparoscopic radical resections with curative intent (32).

In this way the patients can benefit from both the advantages of minimally invasive surgery as well as from the benefits of an R0 resection and intraperitoneal chemotherapeutic administration. However, it should not be omitted that the laparoscopic route of administration of heated chemotherapeutic agents might be associated with a higher intraperitoneal temperature and a significantly decreased heat lost when compared to the open approach; therefore a close monitoring of the intraperitoneal temperature using at least four thermocouples is mandatory (6).

The preliminary results of our cases come to demonstrate that performing L-HIPEC in advanced stage gastric cancer with low PCI values is safe and effective, the perioperative and postoperative evolution being uneventful in both cases. However, association of L-HIPEC and debulking surgery should be performed only in well selected cases. The present study's limitations are determined by a reduced number of cases but, to our knowledge this is the first series of laparoscopic HIPEC addressed to peritoneal carcinomatosis from gastric cancer published in Romania.

\section{Conclusions}

Although peritoneal carcinomatosis from gastric cancer has been considered for long time as a terminal event in which only palliative treatment might be performed, recent studies have demonstrated that association between debulking surgery and administration of hyperthermic intraperitoneal chemotherapy might improve the outcomes of these patients.

However, only few studies have been published so far; therefore, large prospective studies are still needed in order to determine which cases could benefit most from this aggressive surgical procedure. Moreover, it should not be omitted that this kind of surgical strategy might be associated with significant morbidity rates, a careful selection of the patients being mandatory.

Explorative laparoscopy can help select patients for conversion chemotherapy in the setting of high peritoneal carcinomatosis index (PCI) score.

Laparoscopy radical excision + L-HIPEC were successfully performed with very good therapeutic outcomes

\section{Conflict of Interest}

The authors declare that they have no conflict of interest.

\section{Ethical Approval}

Yes, for the introduction of L-HIPEC for peritoneal carcinomatosis from gastric cancer.

Informed Consent: Yes.

\section{References}

1. SADEGHI, B., ARVIEUX, C., GLeheN, O., BeAUjARD, A. C., RIVOIRE, M., BAULIEUX, J., FONTAUMARD, E., BRACHET, A., CAILLOT, J. L., FAURE, J. L., PORCHERON, J., PEIX, J. L., FRANCOIS, Y., VIGNAL, J, GILLY, F. N. - Peritoneal carcinomatosis from non-gynecologic malignancies: results of the EVOCAPE 1 multicentric prospective study. Cancer, 2000, 88: 358-363.

2. CHU, D. Z., LANG, N. P., THOMPSON, C., OSTEEN, P. K, WESTBROOK, K. C. - Peritoneal carcinomatosis in nongynecologic malignancy. A prospective study of prognostic factors. Cancer, 1989, 63: 364-367.

3. YAN, T. D., BLACK, D., SAVADY, R, SUGARBAKER, P. H. Systematic review on the efficacy of cytoreductive surgery combined with perioperative intraperitoneal chemotherapy for peritoneal carcinomatosis from colorectal carcinoma. J. Clin. Oncol, 2006, 24: 4011-4019.

4. GLEHEN, O., GILLY, F. N, SUGARBAKER, P. H. - New perspectives in the management of colorectal cancer: what about peritoneal carcinomatosis? Scand. J. Surg., 2003, 92: 178-179.

5. CHOUILLARD, E., ATA, T., DE JONGHE, B., MAGGIORI, L., HELMY, N., COSCAS, Y, OUTIN, H. - Staged laparoscopic adjuvant intraperitoneal chemo hyperthermia after complete resection for locally advanced colorectal or gastric cancer: a preliminary experience. Surg. Endosc., 2009, 23: 363-369.

6. FACCHIANO, E., SCARINGI, S., KIANMANESH, R., SABATE, J. M., CASTEL, B., FLAMANT, Y., COFFIN, B, MSIKA, S. - Laparoscopic hyperthermic intraperitoneal chemotherapy (HIPEC) for the treatment of malignant ascites secondary to unresectable peritoneal carcinomatosis from advanced gastric cancer. Eur. J. Surg. Oncol, 2008, 34: 154-158.

7. SUGARBAKER, P. H, JABLONSKI, K. A. - Prognostic features of 51 colorectal and 130 appendiceal cancer patients with peritoneal carcinomatosis treated by cytoreductive surgery and intraperitoneal 
chemotherapy. Ann. Surg., 1995, 221: 124-132.

8. JACQUET, P. and SUGARBAKER, P. H. - Clinical research methodologies in diagnosis and staging of patients with peritoneal carcinomatosis. Cancer Treat. Res., 1996. 82: 359-374.

9. SCARINGI, S., KIANMANESH, R., SABATE, J. M., FACCHIANO, E., JOUET, P., COFFIN, B., PARMENTIER, G., HAY, J. M., FLAMANT, Y, MSIKA, S. - Advanced gastric cancer with or without peritoneal carcinomatosis treated with hyperthermic intraperitoneal chemotherapy: a single western center experience. Eur. J. Surg. Oncol, 2008, 34: 1246-1252.

10. FUJIMOTO, S., TAKAHASHI, M., MUTOU, T., KOBAYASHI, K, TOYOSAWA, T. - Successful intraperitoneal hyperthermic chemoperfusion for the prevention of postoperative peritoneal recurrence in patients with advanced gastric carcinoma. Cancer, 1999, 85: 529-534.

11. SUGARBAKER, P. H. and JABLONSKI, K. A. - Prognostic features of 51 colorectal and 130 appendiceal cancer patients with peritoneal carcinomatosis treated by : cytoreductive surgery and intraperitoneal chemotherapy. Ann. Surg., 1995, 221, 124-132.

12. BURKE, E. C., KARPEH, M. S., CONLON, K. C., and BRENNAN, M. F.- Laparoscopy in the management of gastric adenocarcinoma. Ann. Surg., 1997, 225: 262-267.

13. KAMAL, J. M., ELSHAIKH S. M., NABIL, D. et al - The perioperative course and aesthetic challenge for cytoreductive surgery with hyperthermic intraperitoneal chemotherapy Egyptian Journal of Anaesthesia, 2013, 29: 311-318.

14. RASPE, C., PISO, P., WIESENACK, C., and BUCHER, M. Anesthetic management in patients undergoing hyperthermic chemotherapy. Curr. Opin. Anaesthesiol., 2012, 25: 348-355.

15. PRETTO, G., GRANDO, M., CHELLA, N., JR., BERGOLD, R. A., DE CASTRO, R. A., and SANTIAGO, A. - Anesthesia for peritonectomy with hyperthermic intraoperative peritoneal chemotherapy. Case report. Rev. Bras. Anestesiol., 2010, 60: 551-557.

16. MILLER, T. E., ROCHE, A. M., and MYTHEN, M. - Fluid management and goal-directed therapy as an adjunct to Enhanced Recovery After Surgery (ERAS). Can. J. Anaesth., 2015, 62: 158168.

17. CHAMOS, C., VELE, L., HAMILTON, M., and CECCONI, M. - Less invasive methods of advanced hemodynamic monitoring: principles, devices, and their role in the perioperative hemodynamic optimization. Perioper. Med. (Lond), 2013, 2: 19.

18. ALLGAYER, H., HEISS, M. M, SCHILDBERG, F. W. - Prognostic factors in gastric cancer. Br. J. Surg., 1997, 84: 1651-1664.

19. BUZZONI, R., BAJETTA, E., DI BARTOLOMEO, M., MICELI, R., BERETTA, E., FERRARIO, E, MARIANI, L. - Pathological features as predictors of recurrence after radical resection of gastric cancer. $\mathrm{Br}$. J. Surg., 2006, 93: 205-209.

20. YONEMURA, Y., KAWAMURA, T., BANDOU, E., TAKAHASHI, S., SAWA, T, MATSUKI, N. - Treatment of peritoneal dissemination from gastric cancer by peritonectomy and chemohyperthermic peritoneal perfusion. Br. J. Surg., 2005, 92: 370-375.

21. PYRHONEN, S., KUITUNEN, T., NYANDOTO, P, KOURI, M. Randomised comparison of fluorouracil, epidoxorubicin and methotrexate (FEMTX) plus supportive care with supportive care alone in patients with non-resectable gastric cancer. Br. J. Cancer, 1995, 71: 587-591.

22. SCHEITHAUER, W., KORNEK, G., ZEH, G., et al.- Palliative chemotherapy versus supportive care in patients with metastatic gastric cancer: A randomized trial. 68 Second International Conference on Biology, Prevention, Treatment of Gl Malignancy Koln, Germany. 1995.

23. SUGARBAKER, P. H. - Peritonectomy procedures. Ann. Surg., 1995, 221: 29-42.

24. VAN DE VAART, P. J., VAN, D., V, ZOETMULDER, F. A., VAN GOETHEM, A. R., VAN TELLINGEN, O., BOKKEL HUININK, W. W., BEIJNEN, J. H., BARTELINK, H, BEGG, A. C. - Intraperitoneal cisplatin with regional hyperthermia in advanced ovarian cancer: pharmacokinetics and cisplatin-DNA adduct formation in patients and ovarian cancer cell lines. Eur. J. Cancer, 1998, 34: 148-154.

25. OVERGAARD, J. - Effect of hyperthermia on malignant cells in vivo. A review and a hypothesis. Cancer, 1977, 39: 2637-2646.

26. STICCA, R. P, DACH, B. W. - Rationale for hyperthermia with intraoperative intraperitoneal chemotherapy agents. Surg. Oncol Clin. N. Am., 2003, 12: 689-701.

27. DUDAR, T. E, JAIN, R. K. - Differential response of normal and tumor microcirculation to hyperthermia. Cancer Res., 1984, 44: 605-612.

28. VAN RUTH, S., VERWAAL, V. J, ZOETMULDER, F. A. Pharmacokinetics of intraperitoneal mitomycin C. Surg. Oncol Clin. N. Am. , 2003, 12: 771-780.

29. GOLDSTEIN, P., DA SILVA, RG., CABANAS, J., et al. - Management of peritoneal carcinomatosis from colon cancer, gastric cancer and appendix malignancy. Cancer Therapy 2005,3:299-320.

30. HOSKOVEC, D., VARGA, J., ANTOS, F., KASPAR, M., VITEK, P., BENKOVA, K., DYTRYCH, P., and KONECNA, E. - Palliative treatment of the advanced gastric cancer by means of surgery and HIPEC. Bratisl. Lek. Listy, 2013, 114: 735-739.

31. JAYAKRISHNAN, T. T., ZACHARIAS, A. J., SHARMA, A., PAPPAS, S G., GAMBLIN, T. C., and TURAGA, K. K. - Role of laparoscopy in patients with peritoneal metastases considered for cytoreductive surgery and hyperthermic intraperitoneal chemotherapy (HIPEC). World J. Surg. Oncol, 2014, 12: 270.

32. TAKESHITA, K., LIU, Y., ISHIBASHI, H., and YONEMURA, Y. Laparoscopic Hyperthermic Intraperitoneal Chemotherapy for Peritoneal Carcinomatosisfrom Gastric Cancer: Its Beneficial Effects on Reduction and Exact Evaluation of the Peritoneal Cancer Index. Am. Surg., 2017, 83: 1315-1320. 